\title{
THE CRITERIA OF EVALUATING THE ABILITY TO SPEAK FOR CHILDREN OF PRESCHOOL AGE Irina Cupere
}

\begin{abstract}
Human interaction is possible with the help of communication. With the communication activity realization we need to develop our communication competence. Narrative skills development level is human's individual skill, consequently and coherently transmitting his thoughts, knowledge and experience for interlocutor choosing right language tools and grammatical construction. This skills child learns in preschool age and has to develop in throughout life.

Speech disorders, particularly insufficient development of the language system, have important influence on narrative skills development. Further this problem could badly affect the communicative activity realization. For this problem minimization should be help to children to develop their narrative skills. Before starting corrective developing work for children with insufficient development of language system, it is required to assess child narrative skills development level. This is an analysis of children narrative skills development opportunity and practical recommendations.
\end{abstract}

Keywords: narrative skills, narrative skills development level, communication competence, insufficient development of the language system.

\section{Introduction}

The basic function of speech is to serve as a communication tool, which aims are to keep the human social contact and exchange information. With the help of positive interaction with adults, a child develops emotionally and intellectually. Children learn about the world around them, acquire new knowledge and develop existing ones through communicating with others. In order to fully realize the communication activities with others, the child must have well-developed coherent speech, including the ability to speak, because that level of speech development becomes a main component of socialization. To children with language disorders, especially in children with language system underdevelopment, coherent speech is impaired, so communicative activity realization is harmed.

Languages underdevelopment is a systemic disorder where are affected all the components of language - phonetics, phonemic processes, vocabulary, grammar, if the child has normal eyesight, hearing and intellectual level of development (Tūbele, 2002). Children with language system underdevelopment have the malfunction of the monologue speech as a result of coherent speech disorders, which causes difficulty to make a communicative activity. They rarely become communication initiators, comment on their games, it is difficult to 
understand these children for others. Providing assistance of speech therapy to the child timely, this problem can be overcome before school age.

Starting the corrective activity, it is important to evaluate child's development of ability to speak. In this article it is theoretically studied communicative competence of the ability to speak development, criteria for evaluating the level of development and are developed practical recommendations for the evaluation.

Methods: analysis of scientific literature

\section{Communication competence}

Human interaction is possible with the help of verbal communication. To fully realize this interaction with others, humans need to develop their communicative competence. Communicative competence of a person realizes in communication.

Communication process is characterized by a conscious goal setting; developing the realization plan and behavioral program execution in communicative activity that takes place between at least two conversation partners. This process uses a language and a common set encoding system that is understood by all communication partners. The communication process is intended to obtain or transmit information to influence the conversation partner (Ušča, L,ubkina, 2013). It is a two way process and without feedback it is not possible.

The quality of this process is provided by:

- Interaction between communication partners, this process is based on the use of one language;

- Communication partner's individual features: cooperation skills, knowledge of the information structure and form of transfer;

- The quality information channel that defines the human individual psychological characteristics;

- Amount of experience;

- Communication result, which is determined by obtaining information, influence on communication partner and self-fulfillment (Ušča, Lubkina, 2013).

Each person's communicative competence, which is different for each person, has influence on the quality of communication. This development of person sets their experience in communicative activity, development of the ability to speak, psychological characteristics and self-esteem.

Communicative competence is the ability to effectively carry out an effective speech act and speech behavior that promotes social interaction norms inherent in certain ethnic groups (Седов, 2008).

The components of communicative competence are the ability to build a dialogue and monologue, the ability to use different techniques of speech under 
the current situation, using a variety of models in speech (Dzintere, Stangaine, Augstkalne, 2014). Communicative competence is the expression of a particular speech act that provides an effective human communication and interaction with others. E. Apsalons (Apsalons, 2011) stresses that using language publicly, humans pay attention to the selected language resources that should be understandable to conversation partner, which is the main conversing feasibility condition.

The components of communicative competence are speech acquisition system and the consciousness of the speaker's speech operating models and the ability to use dialogue and monologue (Dzintere, Stangaine, Augstkalne, 2014, 116-117).

For children with language system underdevelopment public use of language is more difficult: for the communication partner it is difficult to transmit the information to be decoded. The child's speech is difficult to understand, so conversing is complicated. Ability to perform a monologue for children with underdevelopment language system is poor - they cannot create their own narrative plan and fully realize it. The child's narrative ceases to make sense and chronology of events, he can pay great attention to small details, not describing the key. Stories told by children with language system underdevelopment are uniformly more schematically, mostly consisting of simple sentences that do not expand.

To provide children with experiences of making communicative action it is necessary to organize a variety of special situations in which he can develop a communicative competence and ability to speak.

\section{Narrative skills of preschool children}

Communicative action takes place with the help of speech, which is the human material, transforming historically specific type of communication process, implemented through language (Luse, Miltina, Tūbele, 2012). Speech is divided into two types of external and internal speech. To external speech belong oral (monological and dialogic speech) and written language.

Conversational or dialogical speech is a kind of speech made in the form of a dialogue, which is characterized by brief remarks, deviations from regulatory syntactic structures, a wide range of non-verbal resources and gestures. (Luse, Miltina, Tūbele, 2012).

Dialogical speech is the most basic form of speech, which is formed in communication with one or a few conversation partners, and mainly consists of the questions guiding sentences syntactically undisclosed constructions. According to Čirkina (Чиркина, 2002), dialogical speech, unlike other negotiating partners there are emotional contact, their exposure to one another with facial expressions, gestures, intonation and voice timbre, and the situation is: the subject of consultation or theme exists only between the activity or 
indirectly perceptible. Dialogue is maintained by leading questions, the change of situation and intentions of the speaker.

Monological speech is a monologue form built speech, which is characterized by trying to massively expand certain theme narration grammatical structures drawn-up by the plot line insertions, etc. (Luse, Miltina, Tūbele, 2012). After Čirkina (Чиркина, 2002), monological speech is characterized by continuity which is providing cohesiveness grammatically correct presentation, expressive voice means. During monological speech listeners transfer their knowledge or system events through language. In content and language use of resources it is more complex than in a dialogue speech and the narrator provides a higher communicative competence. After Prisčepova (Прищепова, 2005), monological the speech skills and skills development are the characteristics for speech development as wholeness and coherence. They are closely related to each other, corresponding to communication purposes and characterized by a communicative focus, sets out the logic, structure, determine the means of language organization.

There are three types of monological speech: channelings, description and reasoning.

Language system underdevelopment affects most directly the monological speech, because it is related to coherent speech.

Coherent speech:

- Is long and consists of several sentences;

- Is sequential, logical;

- $\quad$ is programmed as a whole;

- Is a subject to certain regularities (Tūbele, Luse, 2004, 121).

Children with language system underdevelopment speech coherence can be executed only on the basis of an idea of the structure of the expression and characteristics of each stage of the narrative, as well as the internal narrative in its ways. Speech and intellectual development of a high level of first graders with the language system provides insufficient development of language regularities of the high level of awareness, the ability to secrete presented in verb forms as a speech unit (Прищепова, 2005). Therefore it is important to start working on the ability to speak development of pre-school age to school until the child is already learning languages regularities.

Creating a communicative situation where a child can build stories, express thoughts and judgments, it is important to pay attention to the difficulties that appear in the narrative creation of a child and give him support for its realization. The child's stories may be different by content: about toys, recent events, nature, and so on. It is important for a child to talk about certain things known to him, and then speech becomes more cohesive and relaxed.

For preschool children it is easier to learn proper sentence structure, than a variety of links for ways to link the narrative part among them. For children it is easier to portray their stories spatial and temporal sequence of events into a 
single phrase saying, than to reflect the narrative of different types of linkages, secrete a variety of facts, phenomena and explain them. The transition to the associated speech and narration is only possible when the child with language system underdevelopment already knows how to build extended phrases, however, related to the acquisition of the speech need not only to set the linguistic level of development, but also the ability to plan expressible thoughts. Narrative planning and creation of the surrounding is facilitated in case of a narrative line subject matter aspects reflect real events, the sequence of those. In any case, before making a narrative storyline it is necessary to work on planning and selecting of linguistic means. Promoting the ability to speak, it is necessary to develop the lexical and grammatical speech related part. By dialogical and monological speech development needs to organize a variety of communicative situations. In order to promote the child's speech activity it is necessary to discuss different situations more often, to respect the child's views (Люблинская, 1959).

Developing the coherent speech, the child must learn to choose the most appropriate words and word connections, start and build sentences so as to form a flowing narrative and without unnecessary repetitions, acquire the ability to build a compositionally correct narration, which the listener would have done.

\section{Narrative skills species}

The ability to speak is a kind of coherent speech, which needs to be developed as soon as possible, in pre-school age. It is a short or long monological speech with the use of dialogical speech. Monological speech shows its importance of a child's life of 6-7 years. Piaget (Piaget, 1955) notes that in this age group for child the monological speech is leading, when he starts talking about himself and listens to his communication partners. Monological speech is mainly referred to himself, but through communicative action, it may be referred to others. Golubina (Golubina, 2007) on monological speech development criteria defines skill to focus thinking on the main narrative, the ability to speak eloquently and emotionally, the amount of memory, the ability to focus on the speech content and form. To speak eloquently and emotionally, it is necessary to be able to choose appropriate words and other language characterizing expression.

Unlike monological speech, dialogical speech provides two or more conversation partners. Golubina (Golubina, 2007) on the dialogical speech development criteria defines skill to formulate and ask questions of conversation partner, the ability to properly answers the questions, expand partner's thoughts in the conversation, and correct it according to their age to defend their thoughts and opinions.

There are three types of the ability to speak: 
Retelling - the ability to build retellings of what had been read and seen sticking to lexical, grammatical and syntactical area.

Gluhov (Глухов, 2004) and Korotkova (Короткова, 1982) note that retelling develops the child's vocabulary, perception, memory and attention, improves the structure of speech and expressiveness. The child's sentence structure and word structure has evolved, he acquired the skills to assess the accuracy of the expression of language norms perspective.

Describing is the ability to create stories - descriptions. The communicative task of description is to create conversation partner's image of the object using only the language assistance which characteristics and properties are required to provide a certain order. Ability to describe is also closely linked to mental processes - the imagination, way of thinking; thinking operations - analysis and synthesis. Description is to some extent a static object, „photo" phenomenon. In order to successfully create a narrative of the required algorithm it is necessary to teach the child to develop a description of a specific sequence. Algorithm can give a child a picture or symbols (Kaņepēja, 2003).

Narrating with the creative elements of the action is the ability to create stories with creative action elements: languages resources are transferred to interlocutor with own fictional narrative with independently selected content and logically created scenes. According to Zhukova, Mastjukova and Filičeva (Жукова, Мастюкова, Филичева, 1990), the ability to narrate is a way to develop a child's verbal logical thinking, allowing children to express their own thoughts, expressions of personal perception of the links between the different objects and the relationship between them, their ambient perception of the world, promoting the child's knowledge and perceptions of it. Ability to develop creative stories brings the child to that monological speech level of development that will allow him to move from game to teaching.

There are common evaluation criteria for all kinds of the ability to speak: coherence, vividness, independence, the size of the vocabulary and grammatical structure of sentences. Work on the development of the child's ability to speak helps to improve all part of speech: phonetic, lexical and grammatical, as it functions as whole system.

When evaluating child's level of the ability to speak development, it should be considered the child's age group, because the narrative qualitative and quantitative indicators for each age group are different. In order to determine the child's narrative qualitative and quantitative indicators as criteria are used narrative content, the amount of vocabulary and sentence structure. The independence of composed by the child narration can be evaluated by the amount of questions that were asked for understanding the narrative plot line.

The level of development of the ability to speak the child can be determined by how much help from adults it is required to start child's own story. Often leading questions only serve as psychological support to child to start to build his own narration. 


\section{Narrative skills development evaluation}

Evaluating the development of the ability to speak Gluhov (Глухов, 2004) proposes to use the evaluation of five levels. The five-level system makes the ability to speak development evaluation pictorial and practically useable. As the criteria for narrative independence there are used language resources of grammatical part, and a coherency of the narrative flow.

Based on Gluhov's (Глухов, 2004) recommendations for the evaluation of children ability to speak development, these are the best tasks:

- Text retelling;

- Story after topic - a series of pictures (ability to plan narrative, linguistic level of development);

- Narration - description.

Narration is evaluated by narrative integrity, flow and completeness, continuity of accuracy, comprehension and grammatical correctness of the task.

Children's ability to speak is evaluated on the 5 levels:

Level 1: the task is not done. There is no coherency of speech, or of its development level is very low.

Level 2: the task is accomplished with the help of questioning. The child's narrative sequence is harmed. Narration is composed of events, phenomena and operation naming. The literal side of the speech is observably disrupted. The use of language resources is poor and uninformative.

Level 3: during the task the leading questions are re-used. Child may skip certain moments, the whole passage, repeat what already was said. Narrative has noticeable grammatical and lexical gaps. The communication narrative wholeness is reduced.

Level 4: during the task it is required adult's assistance or questioning. Child makes informative and logical narrative. There are difficulties in the realization of ideas, the expression in presentation, making phrases and sentence structure.

Level 5: mission accomplished independently, narration is sequential and coherent. During the telling child selects a large variety of language tools, it is grammatically correct.

\section{Conclusion}

Communicative competence includes the ability to build a dialogue and monologue speech to use different techniques according to current situation, using a variety of speech activity patterns. Communicative competence is the expression of a particular speech act that provides an effective human communication and interaction.

In order to communicate properly, people need well-developed ability to speak which are used in conversation to achieve a positive result. Using different kinds of the ability to speak people transfer to conversation partners 
information which can be received in a number of ways with a help of describing and recounting.

Summarizing and analyzing evaluation criteria of the ability to speak development for children of pre-school age of the mentioned authors can be considered:

- Ability to independently build a sequential, logical, flowing narrative;

- Ability to focus the mind on the main narrative, sticking to the selected plot and narrative perspective;

- Ability to formulate and ask questions of conversation partner;

- Ability to carry out the content of the answers questions;

- Ability to speak imaginatively and emotionally expressive, then selecting the correct language resources;

- Ability to focus on the content and form of speech;

- Ability to find a way of presenting their thoughts to conversation partner, according to their age to defend their ideas and opinions;

- Ability to distinguish verb forms as speech units;

- Ability to supplement what the conversation partner has said and correct it;

- The size of the vocabulary and grammatical structure of sentences.

With the development of the child's ability to speak also develops his communicative competence, which significantly affects a social life. Further it will help him to find his place in the peer group, to establish friendly relations and to reach a chosen profession. For the ability to speak development determination it is recommended to use a five-level system, which makes the results demonstrable. This will help further corrective and developing activity to be more efficient, reflect the child's individual dynamics of development to follow his personal qualities. The five-level system is applicable in practice.

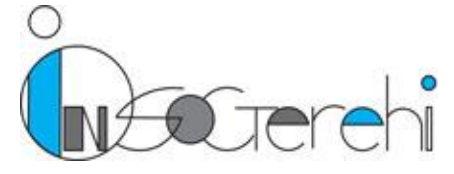

This work has been supported by National Research Program (NRP) "Innovative solutions for social tele-rehabilitation in the schools of Latvia in the context of inclusive education" INOSOCTEREHI

\section{References}

Apsalons, E. (2011). Valodas lietojuma logika. Rīga: Zvaigzne.

Golubina, V. (2007). Pirmsskolas pedagoga rokasgrāmata, Rīga: Izglītības soḷi.

Kaņepēja, R. (2003). Iepazīstināšana ar apkārtni. Literatūra. Runas attīstīšana. Rakstīt un lasītmācīsana.Es gribu iet skolā, Rīga: Puse Plus.

Lūse, J., Miltiņa, I., Tūbele, S., (2012). Logopēdijas terminu skaidrojošā vārdnīca. Rīga: RAKA.

Piaget, J. (1955). The language and thought of the children. New York: Meridian book. 
Tūbele, S. (2002). Skolēna runas attīstības vērtēšana. Rīga: RAKA.

Ušča, S., L,ubkina, V. (2013). Pusaudžu ar valodas traucējumiem komunikatīvās kompetences attīstība. Rēzekne: Rēzeknes Augstskola.

Глухов, В. П. (2004). Формирование связной речи детей дошкольного возраста с общим недоразвитием речи. Москва: АРКТИ.

Прищепова, И.В. (2005). Речевое развитие младиих школьников. Санкт - Петербург: Kapo.

Седов, К. Ф. (2008). Онтопсихолингвистика. Москва: Лабиринт.

Чиркина, Г. В. (2002). Основы логопедической работы сдетьми: учебное пособие для логопедов, воспитателей детских садов, учителей начальных классов, студентов педагогических училищ. Москва: АРКТИ. 